\title{
30. One hand clapping: Reflections on the first anniversary of Fiji's 2006 coup
}

\author{
Brij V. Lal
}

The tyranny of a prince in an oligarchy is not so dangerous to the public welfare as the apathy of a citizen in a democracy.

Montesquieu

Acquiescence is the friend of illegality.

Justice Roger Coventry

The first anniversary of Fiji's December 2006 coup passed uneventfully, without any rallies, protest marches or vigils - merely an exhausted, scarcely audible mutter from the populace hankering for some semblance of normality. A Fijian political activist once likened Fiji to a swimming duck: All calm on the surface but furiously churning underneath. Just how much turbulence there was among indigenous Fijians is difficult to gauge, but its existence was beyond doubt. To forestall any organized opposition, the interim administration slapped on several states of emergency.

Overall, 2007 remained a depressing and miasmic year, with much movement but little change. The military's much heralded 'clean-up' campaign, the principal reason for the coup, was stalled, mired in controversy about its legal validity and true purpose. No one was successfully prosecuted for the misdemeanours for which they had been unceremoniously sacked from office. The judiciary, to everyone's disappointment, remained as divided and demoralized as ever. The constitution remained intact, but often 'ignored or bypassed as deemed necessary'. ${ }^{1}$ International vigilance, manifested in travel bans on members of the interim administration, remained despite official pleas for sympathetic understanding and assistance. Fundamental changes to the electoral system were mooted, including a common non-racial electoral roll, a common name for all citizens, and reform of important institutions of indigenous governance, but there was reservation among many who were already distrusting of the interim administration's motives and its counterproductive confrontational approach to sensitive issues. The metaphor of a duck crossing apparently placid water accurately described Fiji as it marked the first anniversary of the country's fourth coup.

By the end of 2007, blatant breaches of human rights - people hauled up to the military barracks, interrogated and subjected to degrading treatment for alleged 'inciteful' activities or comments or unproven criminal activities - were for the 
most part over. However, the brutal police-military assault in early November 2007 on Ballu Khan, a Fiji-born, New Zealand businessmen suspected of masterminding an assassination plot targeting Commodore Bainimarama, interim Finance Minister Mahendra Chaudhry and interim Attorney-General Aiyaz Sayed-Khaiyum, among others, showed just how tenuous the respect for law and order remained. People observed silence and self-censorship for good reason. The eleven suspects who were apprehended in relation to the alleged assassination plot, among them 2000 coup convict and Naitasiri high chief Ratu Inoke Takiveikata, former intelligence chief Metusela Mua and former land forces commander Jone Baledrokadoka, continue to await trial.

Whether the assassination plot was genuine or a ruse to detract attention from the interim administration's own internal difficulties will be revealed in due course. Already, the initial charge of treason has been reduced to conspiracy to murder, with one suspect freed for lack of evidence. Police commissioner Esala Teleni implausibly implicated un-named foreign governments (no doubt he had Australia and New Zealand in mind) and even some local, again un-named, non-government organizations in a 'conspiracy and consolidated effort to disrupt the peaceful environment in Fiji' ${ }^{2}$ Yet again, there was no evidence. Teleni's assertion that Ballu Khan had suffered only 'minor injuries' - in fact, a fractured skull, broken ribs and other life-threatening internal injuries requiring a month in intensive medical care - served to underline the police commissioner's brazen disregard for the truth, seemingly symptomatic of a larger malaise.

\section{The People's Charter}

An important part of the interim administration's plans for Fiji's future was preparing the so-called People's Charter. The charter's goal is to 'rebuild Fiji into a non-racial, culturally-vibrant and united, well-governed truly democratic nation that seeks progress and prosperity through merit-based equality of opportunity and peace'. ${ }^{3}$ Formulated by a 43-member National Council for Building a Better Fiji (NCBBF), various committees look at issues of good governance; economic growth; social and cultural identity and nation-building; the role of Fiji's security forces in national development; enhancing livelihood; citizenship; and leadership and institutional reform. President Josefa Iloilo launched the charter project in October 2007, and appointed members of the NCBBF in January. Catholic Archbishop Petero Mataca and interim prime minister Commodore Bainimarama agreed to co-chair the NCBBF. Predictably, their appointment provoked controversy.

While Bainimarama's selection was politically necessary - his support was crucial for the project's success - it also politicized the process and impaired its neutrality in the public mind. It effectively ensured that his political opponents, to whom Bainimarama has shown little empathy, would boycott both the charter and the NCBBF. Curiously, Bainimarama expressed puzzlement at public scepticism 
towards his participation, little realizing that he himself was the principal cause of it. John Samy, head of the NCBBF's Technical and Support Secretariat, claimed that the charter initiative was independent of the interim administration, but with Bainimarama as co-chair and several government ministers heading various of its committees, this was unconvincing. As Daryl Tarte, chair of the Fiji Media Council, said in his letter resigning his membership of the NCBBF, the process was clearly driven by the interim government, it was not autonomous and had been compromised.

Archbishop Mataca's inclusion dismayed many Catholics opposed to the military coup and the interim regime, and others who decried the Catholic Church's 'silent understanding' of the reasons behind the coup and the tacit moral support of its leaders. ${ }^{4}$ Mataca is widely regarded as a man of complete integrity and unimpeachable character, and he promised not to be anybody's rubber stamp. But doubts remained. 'By accepting the position [of co-chair]', a Fiji Times editorial said, 'the Archbishop has unwittingly given his approval to the coup, the usurpers and the interim government. Regardless of how noble his motives may have been in accepting the post, the public will always see him and the church in a different light now'. ${ }^{5}$

The controversy continues to simmer, although the Catholic Church, or at least some of its leaders (Fr Kevin Barr, for example), has from the outset taken 'the ends justify the means', social justice over legal justice line, placing faith in the possibility of a positive, genuine, nation-building outcome from the military takeover. 'The legal/illegal paradigm being pursued in Fiji today seems to be getting us nowhere', Barr has written. 'It simple creates an endless cycle of negativity and stalemates.' A democratic society 'cannot be built solely on the rule of law. It demands that the law be balanced by principles of social justice, compassion and common sense. It may not always be helpful to fight for the rigid application of the law' ${ }^{6}$

The charter has received mixed response from the people. Two principal Hindu organizations, the Arya Pratinidhi Sabha and the Sanatan Dharam Pratinidhi Sabha, have supported it and agreed to participate in the deliberations of the NCBBF. However, with apparently little widespread consultation - if letters to the editors in the local press are anything to go by - there remains uncertainty about rank-and-file endorsement of the leadership's decisions. Other Indo-Fijian religious and cultural organizations have refused to participate in the proceedings of the NCBBF. The Fiji Muslim League and Sangam (representing the South Indian community) are among them. The endorsement by Indo-Fijian cultural and social organizations, representing a large section of the community, sends yet another signal to those Fijians opposed to the coup that the Indo-Fijian community is silently (and sometimes not so silently) supporting the interim administration and benefiting from its policies. Yet, some of the most prominent 
critics of the coup (such as Shamima Ali, Imrana Jalal, Wadan Narsey and Richard Naidu) are also Indo-Fijians.

All the talk about the charter in Suva means little in the countryside where Indo-Fijians suffer from the effects of a seriously ailing sugar industry and the dislocation caused by the expiry of land leases. Making ends meet, both in urban and non-urban areas, is becoming harder by the day as prices of basic food items and fuel keep rising and employment opportunities diminish. But perceptions matter and acquire a reality of their own. When an interim minister, the FLP's Lekh Ram Vayeshnoi, calls the coup a 'Godsend,' when academic Sukh Dev Shah describes it as 'divine intervention,' and as Indo-Fijian gloating becomes more audible on radio talk-back shows and in the letters to the papers, the indigenous Fijian perception becomes easier to understand - and harder to ignore.

Several Fijian provincial councils have also endorsed the charter, including Cakaudrove and Kadavu. But this endorsement is fraught and carries little weight. For instance, Cakaudrove's endorsement of the charter has been challenged by Ratu Naiqama, the Tui Cakau, the paramount chief of the province and a former minister in the Qarase government. A spokesman for the chiefly Lalagavesi clan of Cakaudrove, Epeli Matata, said emphatically that Ratu Naiqama and the whole province of Cakaudrove 'is not supporting, has never and will never support, the work involved in the People's Charter'. ${ }^{7}$ Individuals from other provinces and regions have similarly offered strong contrary views - for example, Kadavu Provincial Council chairman Ratu Josetaki Nawaloawalo's enthusiastic support for the military takeover and subsequent events has been publicly challenged by people from his own province. ${ }^{8}$

Embroiling the provinces in the adoption (or rejection) of the charter is politically fraught, for no place is (and never has been) of one mind on any political issue. Provinces don't vote; people do. The power of chiefs to decide the destinies of their people, to be their sole spokesman and intermediaries with the outside, has long gone as travel, technology, education, the effects of a competitive market economy and exposure to broader forces of change have altered the fabric of Fijian society. Over the last two decades or so, political fragmentation rather than political unity under chiefly leadership has been the order of the day in indigenous politics. In the absence of strong, overarching leadership and broader unifying vision, dissension among Fijians will only grow. Signs of this are everywhere. It would be wise for the provinces to adopt a more neutral stance, as facilitators of political discourse among their people rather than as its arbiters.

While some support the charter opportunistically - a government contract here, an appointment to a statutory board there, a rare opportunity to network, a brief moment in the public limelight - there are also some who genuinely believe in the Utopian future the charter promises for Fiji. A genuine sense of frustration with the manner in which parliamentary democracy has been manipulated by 
the ruthless politics of race, has led some academics and professionals, normally staunch supporters of parliamentary democracy and the rule of law, to endorse the shock therapy of the military coup. They want the racial system of voting abolished and see the preparation of the charter as the perfect opportunity to break the confining shackles of the past. Some believe it is sometimes necessary to go outside the law to preserve its spirit.

There are others who have little regard for 'people's democracy' and support the charter because, they say, people do not know what is in their own best interests, and that they are their own worst enemies and are invariably manipulated by self-seeking politicians. Hence, they argue, it is best to do their thinking for them, relieving them of the responsibility of making decisions for their future. The charter would put the nation's affairs on autopilot, with the elected parliament, when it finally eventuates, making only minor adjustments to public policy. Politics of the usual raw and vital type will be removed from the process of governance. The fundamentals of good governance will be permanently entrenched in the public sphere, and politicians will become irrelevant. 'Politics,' for these people, is a 'dirty' word which creates more problems than it resolves. 'Revenge of the nerds' is how one colleague described this category of charter supporters, meaning well-heeled bureaucrats, academics, international civil servants and the like.

The charter has strong critics as well. ${ }^{9}$ The Soqosoqo Duavata ni Lewenivanua (SDL), the Methodist Church and the Fijian Teachers Association, among many others, have opposed it and refused to participate in the deliberations of the NCBBF. Their reaction is unsurprising. They see the charter as an attempt by the military to emasculate the SDL party and exclude people like Laisenia Qarase from standing for office in the future. They see it as neither a part of the constitution nor an act of parliament. How then, could the document be used to deprive people of their basic constitutional right? Given Bainimarama's uncompromising stance and vehemence, Qarase is right to be cautious, justifiably feeling that the military intends to use the charter as a blunt, coercive instrument to bludgeon him and his supporters into acquiescence - or, worse, political extinction.

Fijian nationalists oppose the charter because they see the document as diluting their privileged place in national life. They want a Fiji where Fijian aspirations and interests are respected and accorded primacy, not subordinated to the interests of others. For them, that is right and proper. This, after all, was what their leaders, from Ratu Lala Sukuna to Ratu Mara, told them - their vision endorsed by the departing colonial masters. ${ }^{10}$ The interim administration's forceful rhetoric of non-racialism stirs their suspicion and stokes the embers of ethnic chauvinism, as does its efforts to reform Fijian institutions, such as the Native Land Trust Board and the Great Council of Chiefs (GCC), long cherished 
as the guardians of the Fijian interest. The fact that many Fijians see Mahendra Chaudhry as the 'man running the government,' calling 'all the shots', with Bainimarama being a mere figurehead, adds a particular dimension to the drama. ${ }^{11}$ One highly mobile and educated Fijian lady put the whole issue to me this way: 'It is okay to criticise individual Fijian chiefs who are corrupt or morally bankrupt. I do it all the time myself. But when you attack Fijian institutions, then my heart begins to hurt. They are a part of our cultural identity. That is what makes us what we are.' I suspect that her sentiments are widely shared by many other indigenous Fijians.

There are others whose opposition to the charter is ideological. For them the constitution is, and should always be, the supreme law of the land. They see the charter as a way for the military to supersede the constitution, rendering it a toothless tiger or, to change the metaphor, a hollow vessel to be filled with whatever ideology it wants. The affairs of the nation, they say, should be run by an elected parliament, the supreme repository of the people's freely exercised choice, not by unelected people serving in an illegal regime. The real problem for Fiji, they argue, is not the absence of a charter defining the principles and purposes of governance: The Compact in the 1997 constitution already provides for these. The real problem is the lack of respect for the rule of law and the verdict of the ballot box, of which the military is the principal culprit.

A charter, however well-intentioned, will not eradicate the deepening coup culture in Fiji or eliminate the troubling disrespect for the rule of law. Today, it is a commodore's charter; tomorrow it could be another colonel's political agenda. Former land forces commander Colonel Meli Saubulinayau, who resigned from the military in 2007 after a botched effort to replace Bainimarama as head of the military force, has expressed a widely held view that Fiji does 'not need another piece of paper as we already have one that talks about the law and what is legal. If you want to stop the coup culture, then you need people who have a spirit that wants to stay within the boundaries of the law' ${ }^{\prime 2}$ Fiji's coup culture could end only if the military, and especially its commander, decided to end it.

People are being asked to endorse a document which will profoundly affect their lives, but in whose formulation they have had a perfunctory say. The hand-picked drafters of the charter and the military have already made up their minds about what the charter's content and parameters would be: Bainimarama's railings against Qarase are proof enough of that. Normally in a democratic society, a document such as the charter would have been formulated after an extended period of consultation with the public, not before it. The interim administration has promised a national referendum on the charter. But this is easier said than done.

Referenda on controversial, divisive issues hardly ever succeed. A near-consensus would have to be reached among the major stakeholders if a referendum were 
to have any realistic prospect of success. With all the major players poles apart, it is almost certain that a referendum on the charter will fail if there is a meaningful threshold for its successful passage. What is not sufficiently appreciated in Fiji is that a failed referendum will be worse than no referendum at all, closing off doors to further conversation which might otherwise have remained open. Referenda are risky propositions even at the best of times. A Fiji Daily Post editorial summed up the charter conundrum well:

The danger of asserting one-sided settlements is evident in that great chain of events that led to the rise of nuclear warfare at the end of WWII. By the same principle, a one-sided 'People's Charter' for Fiji may not have the ameliorative effect its enforcers hope for. To truly succeed, the charter, like the nation, must proceed by bipartisan agreements, by consultative dialogue that brings victors and vanquished to the table of compromise so that a just settlement is achieved. ${ }^{13}$

\section{The military}

The military has assumed the role of guardian and facilitator of the charter. At first there was no discussion about the role of the military in Fiji's future. As Inspector Nasir Ali remarked in another context (investigating corruption), touching the military would be 'suicidal'. Following public comment, one of the working groups of the NCBBF has promised to look at the 'role of Fiji's security forces, including the military, in national development'. ${ }^{14}$ 'Looking' is more likely to end up entrenching the military in the public-political sphere and enhancing its 'national' developmental role. Meanwhile, the military marches on undaunted. Since the coup, it has hardened its grip on the most important levers of power. Commodore Esala Teleni heads the police force, Colonel Ioane Naivalarua is commissioner of prisons, and Captain Viliame Naipoto heads the Department of Immigration. Several others have been placed in strategic positions in the civil service and in district administration. All this may not be tantamount to the 'militarization' of the civil service in the conventional sense, but it does corrode its morale and cause a 'clash of cultures' between the military personnel transferred to the civil service and those who have come from a civilian background. 15

The established rules and procedures of public service are flouted with impunity because the protocols that govern the conduct of military operations do not always accord with those that regulate public service. And this, said The Fiji Times, was 'something known to be worrying many officers who have fought for years to lift the standard of the force'. ${ }^{16}$ Former military spokesmen Lieutenant Colonel Mosese Tikoitoga has said that the 'Military Council was of the view that there needs to be more involvement of officers in the civil service because those who were there were not producing results and not doing their 
jobs. The attitude of the civil service needs to be changed and those that didn't change should move on or be removed' ${ }^{17}$ The monitoring and assessment of the performance of the civil service is, or should be, the responsibility of the Public Service Commission, not the military, which itself, curiously, remains unaccountable to anyone except itself.

The checkpoints and the military patrols of the streets are gone, but the military's grip on the country has strengthened. There is a military council, comprising senior serving and former officers, whose representatives sit in on cabinet meetings, and make recommendations to Bainimarama on the performance of ministers and on other matters of importance. The council has no legal foundation, and its existence was revealed accidentally to the wider public late in 2007. But of its powerful advisory role there is no doubt. Bainimarama has vested the executive authority of the country in the military council, precisely how and when remains a mystery.

The early hope among some members of the deposed government of fomenting dissent in the ranks of the military has long vanished. Bainimarama's hold on the loyalty of his troops seems complete and unshakeable, despite occasional talk of restiveness in the ranks and the distant prospect of an uprising against him. He is the paramount chief of their vanua, which is the military. He is solicitous of the welfare of those under his command. The military intends for itself a permanent and visible presence in national life. The military, Captain Viliame Naipoto has said, 'is my answer to killing the coup culture'. ${ }^{18}$ It is a thought filled with profound implications for the future of Fijian politics: Putting the colonels and commodores in charge of the nation to prevent future coups. It is probably too subversive -'inciteful,' to use a currently fashionable word to disband the military or, at least, substantially reduce its size and operational role. If the military remains adamant about its increased and more visible role in the affairs of the state, then we may have seen the last of the Westminster-type civilian democracy in Fiji.

\section{Elections}

Will a general election be held in the early part of 2009? ${ }^{19}$ This is an undertaking the interim administration gave to the Forum Secretariat in March 2007, and which Bainimarama affirmed at the Forum leaders meeting in Nukualofa, Tonga, in mid-October 2007. ${ }^{20}$ An early election is doubtful as the interim administration has shown no enthusiastic commitment to putting in place the electoral infrastructure for holding one. Focused principally on the People's Charter, its public utterances on the subject are at odds with the reality on the ground. The FLP has opposed an early election, with Chaudhry saying that 'general elections will be held when the necessary groundwork is complete'. ${ }^{21}$ Precisely what these words imply is difficult to decipher - what constitutes necessary 
groundwork, according to whom, for what precise purpose? - but the intention to delay is unmistakeable.

In a meeting with Indian officials in New Delhi, Chaudhry is reported to have mentioned June 2010 as the possible date for the next election, ${ }^{22}$ echoing the date Bainimarama had mentioned in one of his early addresses soon after taking power. As the year ended, the military council was adamant that the election would be held only when the People's Charter had been accepted. This also became Chaudhry's mantra. 'The charter,' he said, 'should be put together first before the election because we need to address many problems we are facing in this nation. We have to address problems and put our fundamentals right before an election is held'. ${ }^{23}$ Once again, what constitutes 'fundamentals', remains unclear. With widespread disagreement in the community over the charter, consensus is unlikely to be reached and, therefore, the election is likely to be delayed. The interim administration has promised to finalize the charter by the end of 2008, but at the present pace of progress, that is unlikely to be achieved.

The consequences of not holding a general election within a prescribed timeframe will be severe for Fiji. The European Union is unlikely to release funds to help restructure the ailing sugar industry. Travel bans will remain in place, leaving the vital tourism sector in the doldrums. And race relations, already severely strained, will harden even further. Reconciliation, if and when it comes, will be more difficult to achieve because emotions are deeply roused about who was, and was not, behind the coup and the events that have followed. Chaudhry's election-delaying position is understandable from a purely pragmatic, self-serving political stance: Why hold an election when you are already in power and enjoying the fruits (with the backing of guns no less) without being accountable to anyone? But it is also a short-sighted view, a Pyrrhic victory, and provocative in the extreme to those deposed from power by military force.

People in power in the FLP-RFMF interim administration appear unconcerned about the incontrovertible fact that a large cross-section of the indigenous Fijian community feels deeply humiliated. They are the outright majority of the population, and in their view they are the underprivileged ones who needed special assistance, who as the taukei, the indigenous inhabitants, were 'by right' entitled to control the levers of power. And now this: Unceremoniously tossed out of office, deprived of government handouts, and told to compete on equal terms with everyone else. The days of state-sanctioned pampering are over.

It is a timely, if severe, message relayed with unprecedented bluntness. If the SDL and the nationalists ever return to power, they would likely pursue an ethno-nationalist agenda with a vengeance never seen before in Fijian politics. It will be the politics of grudge and relentless score-settling all over again. This is a fear that lies deep at the back of the Indo-Fijian mind. This is the main reason why so many are so desperate for the military to succeed in its campaign. For, 
if it fails, Indo-Fijians know they will be doomed permanently to a subordinate future in the cul-de-sac of Fijian politics from which escape will be difficult.

\section{The rocky road}

Early in January 2008, Bainimarama reshuffled his cabinet, demanding more stringent performance from his ministers - some of whom, as the Fiji Sun noted, were 'notable failures' and some who saw 'their appointments as opportunities to serve themselves and their political cronies rather than their nation while others have been inactive to the point of invisibility'. ${ }^{24}$ Four new faces joined the interim line-up: Dr Jiko Luveni, a close relative of FLP party president Jokapeci Koroi; Filipe Bole, unsuccessful National Alliance candidate in the 2006 election (who, curiously, suggested that those opposing the People's Charter should leave Fiji) a naval officer, Captain Lesi Natuva, and former FLP senator Tom Ricketts.

The new line-up revealed the true identity of the interim cabinet. FLP and National Alliance members controlled many of the most important portfolios: Finance, national planning, sugar industry and public utilities (Chaudhry, FLP), labour, industrial relations, employment, local government, urban development and housing (Vayeshnoi, FLP), trade, tourism and communications (Ricketts, FLP), education, national heritage, culture and arts, youth and sports (Bole, Alliance), defence, national security and immigration (Ratu Epeli Ganilau, Alliance) and primary industries (Alliance-leaning Jo Cokanasiga). It is an impressive haul by any measure, making clear where power lies in Fiji and why Chaudhry is so reluctant to hold an early election. Those who were dumped from the interim administration were promptly rewarded with appointments to the Public Accounts Committee (Transport Minister Manu Korovulavula, Minister for Women's Affairs Laufitu Malani, Agriculture Minister Jainend Kumar). Taito Waradi, the sacked Commerce Minister, was appointed chairman of the Fiji Development Bank. In this revolving-door politics, no one really lost out. It was a pattern familiar from the past, and for which the Qarase government paid a heavy price.

The 'clean-up' campaign, the crucial raison d'être for the coup, has for all practical purposes stalled. Without any credible evidence of wrongdoing unearthed even after the most intensive searches, ${ }^{25}$ or any successful prosecutions taking place, it is possible to wonder whether any wrongdoings occurred in the first place, or were merely politically motivated suspicions about the political loyalties and personal agendas of those targeted. The legal foundations of the Fiji Independent Commission Against Corruption have been questioned. ${ }^{26}$ Launched with great expectations, it has been unable to deliver in a satisfactory manner. It remains without a chair after Malaysian lawyer and president of LAWASIA, Mah Weng Kwai, after initially accepting it, declined the appointment due to considerable pressure from the legal fraternity in Fiji. 
The tribunal to investigate the charges against deposed Chief Justice Daniel Fatiaki, was appointed almost a year after he was sent on enforced leave - on full pay. ${ }^{27}$ The division in the judiciary remains - and in public perception its independence impaired - despite acting Chief Justice Anthony Gates' assertion to the contrary. ${ }^{28}$ In June 2007, Fiji Indigenous Lawyers Association president Samuela Matawalu called for the immediate resignation of Justice Gates, viewing his appointment 'with disdain' because it came about 'as a result of a conspiracy to remove the constitutionally appointed incumbent'. ${ }^{29}$ Judges critical of post-coup developments and the patent illegality of some subsequent activities, have resigned. They include Justice Gordon Ward, president of the Court of Appeal, and High Court Judge Roger Coventry. 'I have been concerned with the speed with which cases of fundamental importance are progressing', Coventry told his farewell audience in January 2008. 'I am concerned that acts, which on their face appear to be unlawful, are being presumed lawful until the court rules otherwise. I am concerned that in circumstances that require a judge or judges to take a particular course of action, that that course is not being taken' ${ }^{30}$

The resignation of the entire panel of the Fiji Court of Appeal was a matter of grave concern. Jurists from Australia and New Zealand have refused to serve on the Fiji courts, leading the Attorney-General to look further afield, to southeast Asia, India and Africa, but so far without success. Two judges from Malaysia appointed to the Court of Appeal last year have yet to take their oath of office, and may even refuse to do so. Meanwhile, judges from the High Court, with limited experience on the bench - some as little as a year - are sitting on the Court of Appeal and the tenure of some judges who are long past the retiring age has been extended. The 'stacking' of the Appeal Court is a matter of grave concern to the legal fraternity in Fiji. So, too, is the injudicious manner in which some judges make comments on controversial political issues. ${ }^{31}$ The Fiji Law Society (FLS) has refused to recognize judges appointed since the 2006 coup because it believes that the appointments were in breach of the constitution. Judicial appointments are made by the Judicial Service Commission, of which the president of the FLS is a permanent member. Appointments were made without the FLS president's presence or participation. ${ }^{32}$

The interim Attorney-General, Aiyaz Sayed-Khaiyum, embarrassed both the Office of the President as well as the interim administration through flawed legal advice. He recommended the appointment of Adi Koila Mara as chair of the Constituency Boundaries Commission when she was clearly ineligible due to her former role as a GCC nominee in the Senate. Section 77 of the constitution prohibits appointment to the Commission of anyone who has been a member of parliament, or of a local authority or any other representative body prescribed by the parliament during the immediately preceding four years - to avoid conflict of interest. Perhaps a more grievous error was the breach of section 76 of the 
constitution, which authorizes the President to appoint the chair of the Boundaries Commission, acting in his own deliberate judgment, following consultation with the Prime Minister and the leader of the opposition. Khaiyum took it upon himself to apologize for the wrong advice to the President. But it was not his advice to give in the first place, for the Attorney-General is the chief legal advisor to the government. He is a political appointee. The head of state seeks legal advice from the Chief Justice or other senior members of the judiciary. The Attorney-General had quite clearly crossed the line. But mistakes did not matter, or were routinely ignored: As a reward for loyalty and brazen outspokenness in defence of the interim administration, Khaiyum had his portfolios expanded in the January reshuffle to include public enterprises. In February 2008, he gained added negative publicity for preventing members of the International Bar Association from entering the country to look at the functioning of the judiciary in Fiji, claiming that the timing was inappropriate as a number of important constitutional cases were before the courts.

The most embarrassing episode to date in the life of the interim administration without doubt, is the revelations about Mahendra Chaudhry's irregular tax affairs. Oxford-based political commentator and former Fiji journalist Victor Lal had been publishing a series of articles about Chaudhry's tax affairs in the Fiji Sun without naming him. When, in February 2008, Chaudhry dared local journalists to name the errant, tax-evading minister, the The Fiji Times did precisely that. ${ }^{33}$ Among the revelations was the non-disclosure to Fiji tax authorities of bank accounts that Chaudhry held in Australia and New Zealand, which over time had accumulated over \$1.6 million. He paid tax on interest earned only after the Fiji Islands Revenue and Customs Authority (FIRCA) discovered the deposits under a bilateral tax treaty. Bainimarama refused calls for Chaudhry to resign or step aside, as urged by the military council, or to have FIRCA officials working on the case (but who had by then been either removed or sent on leave) complete their investigation. 'The issue with Mr Chaudhry is just between him and myself and no one else', he said. ${ }^{34}$

An investigative committee with narrow terms of reference, hastily and secretly organized by the Attorney-General, cleared Chaudhry of any breach of the Fiji Tax Act, but many questions remained unanswered. It was revealed that large sums of money deposited in Chaudhry's Australian accounts came from India and had been channelled through the Indian Consulate in Sydney. The papers indicated that the money was a personal gift to Chaudhry, to enable him to settle in Australia because his life was in danger in Fiji, but Chaudhry had claimed that the money was being held in trust for his community. The FIRCA officials found no deed of trust or any other such document. Chaudhry claimed in January 2003 that he had not received any money from India when the documents showed that it was already in his account in Australia. ${ }^{35}$ In December 2005, Chaudhry, in response to questions from then Prime Minister Laisenia Qarase, categorically 
denied receiving money from India, indicating that people in the Indian state of Haryana had raised money in his name to 'assist with the struggle of the people of Indian origin here'. 36

Chaudhry's opponents gleefully surmised that the tax saga would finally sink his career. ${ }^{37}$ That is unlikely, though some former FLP party members have publicly criticized their leader for his participation in the military's interim administration. ${ }^{38}$ The critics were peremptorily sacked from the party. Chaudhry's hold on the sugar belt remains strong. He has put his loyal supporters in important positions in the sugar industry. He is also the Minister for Sugar as well as the general secretary of the National Farmers Union, from which position he has refused to resign despite the appearance of a conflict of interest: He is, in this case, both the defence attorney as well as the presiding judge. What the saga has done is dimmed his reputation and tarnished his image as a clean crusader for good governance; muddied the high moral ground he has always claimed for himself and his causes. Mahendra Chaudhry will be remembered in future as much for his sad, sorry tax saga as for the courage and tenacity he has shown in his long and turbulent political career, the sacrifices he has made and the hardships suffered.

If Chaudhry was one casualty of the sordid tax affair, the Fiji media, in particular the publisher of the Fiji Sun, whose newspaper had broken the story in the first instance, was another. Russell Hunter was summarily deported under the cover of darkness in late February 2008 by the interim administration, for apparently violating the conditions of his work visa and because he was a threat to 'national security', however broadly that was defined. What precisely the visa conditions were, what 'credible evidence' of Hunter's wrongdoing the interim administration had, were never divulged to the public. ${ }^{39}$ More troubling was the state's defiance of a High Court order prohibiting Hunter's expulsion. ${ }^{40}$ A hastily introduced amendment to the Immigration Act made the minister of immigration's decision unchallengeable in the courts. A few weeks later, the publisher of The Fiji Times, Evan Hannah, was summoned to 'meet' Attorney-General Khaiyum about the coverage his paper gave to the affairs of the interim administration. ${ }^{41}$

Hunter's deportation (see chapter 14, this volume) and perceptions of intimidation of the media brought much local as well as international criticism to the interim administration. Chaudhry has also floated the idea of licensing the media along the Singaporean model, a curiously incongruous proposition coming from the leader of a party which professes to champion the cause of democracy. At the same time, the widely criticized, angry and rambling Fiji Human Rights Commission-sponsored report on the media in Fiji also made recommendations, the net effect of which would be further muzzling of the media. ${ }^{42}$ As the interim administration struggles to provide a semblance of stability to the country, the media will continue to be blamed for all manner of things, inducing a degree of 
self-censorship and fear of intimidation, and infringing its rights and responsibilities as the Fourth Estate.

When Bainimarama executed his coup, he expected the international community to support his 'clean-up' campaign. The FLP's participation in the interim administration also encouraged that thought. But the coup-makers underestimated the response of the international community. At a private meeting with local businessmen, Commodore Bainimarama was told, so I understand, that international resolve against the coup would be short-lived, weakening after about six months, whereupon normalcy would swiftly return, following the pattern of earlier coups. Clearly, that has not happened, nor is it likely to anytime soon. The election of the Rudd Labor government in Australia was touted by some in the interim administration, including Mahendra Chaudhry, as heralding the possibility of more understanding and dialogue between the two countries, leading hopefully to the relaxation of the travel bans on members of the interim administration and their families. That eventuality is hardly likely and would be politically unwise, contradicting Australia's long-held position on the importance of democratic rule in the region and beyond. Winning power through a democratic election after eleven years in the wilderness, Australia's Labor government could scarcely be expected to support a regime that had seized power through a military coup. Moreover, Australia formulates its policy on Fiji in consultation with its neighbours and allies, especially New Zealand, whose anti-coup stance was long-standing, and the European Union and the Commonwealth Secretariat. Labor's pre-election stance on Fiji was clear, 'The illegal seizing of power by Commodore Bainimarama remains an affront to democracy and justice'. ${ }^{3}$ Labor leader Kevin Rudd was equally blunt, 'Democracy and the rule of law must prevail throughout the South Pacific region, so to see both stamped on by the military in Fiji is acutely unwelcome'. ${ }^{44}$ How, in the face of these unequivocal declarations, could the interim regime expect cordiality from Australia defies credulity. Perhaps this was Fiji politics as usual again, words spoken for a gullible public's consumption, but not intended to be taken seriously.

\section{The Fiji Human Rights Commission}

Early in 2007, the director of the Fiji Human Rights Commission (FHRC), Dr Shaista Shameem, gained considerable notoriety, both in Fiji and overseas, for her enthusiastic endorsement of the December coup, which brought her into a sharp verbal exchange with one of the Human Rights Commissioners, Shamima Ali, and with the Fiji legal fraternity generally. In her earlier report, Shameem had effectively blamed the Qarase government for causing the coup, holding it responsible for blatant abuses of human rights and for launching a program of 'ethnic cleansing.' She issued a second 'investigative' report on the coup in August 2007, claiming that the military takeover on 5 December 2006 was not 
a coup. It was, instead, a constitutional removal of a corrupt, human rights-breaching government by the head of state who was exercising powers conferred upon him by section 86 of the constitution: 'The President is the Head of the State and symbolises the unity of the State.' The section, she contended, gave the president far-ranging 'sovereign prerogative powers' which he could exercise constitutionally at his discretion for the good of the state. ${ }^{45}$

Shameem's 'eccentric legal interpretation,' as her critics put it, was seriously flawed and largely disregarded. The simple fact is that under the 1997 constitution the executive does not enjoy unrestricted power. The President acts on the advice of the prime minister or cabinet except for 'very limited situations where he or she has discretion'. ${ }^{46}$ The President's reserve powers are carefully prescribed and circumscribed. The limiting of the sovereign's power has been the thrust of constitutional development since the 18th century, when the concept of 'divine right to rule' began to be reined in. A coup by any other name is still a coup, and attempting to veil the 2006 coup as merely a constitutional removal of a government is, on the face of it, simply too inventive to take seriously. ${ }^{47}$

Not content with seeking to remove the legal legitimacy of the Qarase government, Dr Shameem authorized an enquiry into the fairness and validity of the 2006 election. Predictably, the three-person enquiry, chaired by local lawyer G.P. Lala, and largely boycotted or ignored by all except the FLP, found minor discrepancies in the counting of ballot boxes and some irregularities in the registration of voters that particularly disadvantaged Indo-Fijians. But most people in Fiji believed, as the international election observers had certified, that there was no massive rigging of the election and that the whole enquiry was a politically motivated affair designed to embarrass the Qarase government and to provide a thread of legitimacy to the interim administration. There was room for improvement in the electoral administrative arrangements, to be sure, but the final outcome would not have been affected. Still, politically inspired rumours of rigging persist, becoming a part of Fiji's political culture and raising doubts in the public mind about the legitimacy of election outcomes which have not gone one's way.

As the year ended, the ever combative Dr Shameem launched an enquiry into the funding of Duavata Initiative Limited, the commercial arm of the SDL Party. She was concerned about the manner in which the Initiative had solicited funds from donors before the election. The Duavata Initiative is a private, limited liability company registered under the Companies Act, legally entitled to solicit funds and pay tax on its generated income. The company is not required under Fiji laws to reveal its audited accounts, unlike a statutory organization such as the Native Land Trust Board or the Fiji Sugar Corporation. That the FHRC should undertake such an enquiry seemed only another politically motivated initiative, 
raising further suspicions among indigenous Fijians, the overwhelming majority of whom support the SDL. A further question to be asked is whether or not it is an appropriate use of public money to have an enquiry into the fund-raising activities of a private company, when genuine abuse of human rights (the assault of Ballu Khan, the deaths of civilians in police or military custody) go uninvestigated.

On 31 March 2008, the FHRC issued yet another 'Special Investigations Report,' this time on an alleged Australian intervention in Fiji immediately before the 2006 coup. It claimed that Australia was in breach of international law by seeking to influence events in Fiji (by sending in SAS personnel), by despatching warships before the coup - ostensibly to evacuate Australian citizens when in truth the motives were more sinister - and, by, in concert with other countries, trying to incite mutiny within the ranks of the Fiji Military Forces against Commodore Bainimarama, who was then in New Zealand. The report provides a chronology of events leading up to the coup.

Australia has predictably rejected any ulterior motives other than the safe evacuation of its citizens in the state of emergency. ${ }^{48}$ The Human Rights Commission's allegations are akin to those levelled against the United States in the 1987 coup. ${ }^{49}$ The actual truth may never be known: Such allegations are easier to make than to prove. In this case, Dr Shameem had gone on a 'fishing expedition,' seeking explanations, drawing attention to omissions of factual information concerning certain episodes and events, highlighting contradictions in official responses; but there are no 'direct hits,' so to speak, no concrete proof of Australia's intention to intervene militarily in Fiji. And there the matter rests. One thing is clear: The report is not taken seriously even by neutral observers because of Dr Shameem's close identification with, and support for, the coup and the interim administration. This, we can rest assured, is not the last report that will emanate from the fecund pen (or word processor) of the director of the Fiji Human Rights Commission.

\section{Road map}

As 2007 unfolded, the interim administration, grappling with the niggling problems of running a country amidst diminishing opportunities and sullen opposition, subtly changed the tune about its purpose. The military's rationale for the coup had been the removal of corruption and the promotion of good transparent governance. This rationale was now hobbled. The promise in the 'Road Map for the Return to Parliamentary Democracy' issued in February 2007 to 'introduce measures to kick-start the national economy' remained unrealized. ${ }^{50}$ So too was the promise to 'resolve the land-lease issue,' and 'create more jobs for our people, provide them with better income and opportunities, and reduce poverty'. Instead, twelve months later, poverty was on the rise, squatter settlements were mushrooming, violent urban crime was a serious concern, the 
tourism industry was down, and unemployment was rising. ${ }^{51}$ The rhetoric of change and betterment could not hide the grim reality of despair on the ground. ${ }^{52}$ But Bainimarama remained unperturbed, seemingly oblivious to the many unresolved problems swirling around him. Indeed, one of the more fascinating developments of 2007 in Fiji was the growing ease and confidence, arrogance in the view of his critics, with which he was getting accustomed to and enjoying his power. He attended the Forum Leaders meeting in Tonga and addressed the 62nd Session of the UN General Assembly in late September. There, he continued to present himself as a selfless servant of his nation, a reluctant warrior who only entered the fray at the last minute to save his nation. He characterized a disintegrating Fiji under Laisenia Qarase, experiencing 'a pervasive increase in corruption; serious economic decline combined with fiscal mismanagement; a sharp deterioration in the law and order situation; and deepening of the racial divide in the country.' That was not all.

The convicted coup perpetrators were prematurely discharged from prison, and certain coup perpetrators and sympathisers were appointed as senior Government Ministers and Officials. There were also a series of legislations [sic] that were deeply divisive and overtly racist. ${ }^{53}$

This simplified and self-serving rendition of events needs little comment. But this was the message that the military and the interim government strove to propagate, often to their puzzlement, to unreceptive and unresponsive audiences.

In February 2008, Bainimarama appointed himself chairman of the GCC, thereby becoming the most powerful man in modern Fijian history: Head of the military, the government and the supreme body of the indigenous community. As chair of the GCC, Bainimarama will appoint, theoretically on the advice of the provincial councils, 52 members of the Council. He could 'suspend, discipline or dismiss any member who brings disrepute to the Council'. No Fijian, chief or otherwise, will be eligible for the membership of the Council if he or she has served a prison term, is an undischarged bankrupt, has contested a general election, was a member of parliament (both the House of Representative and the Senate) or was an office bearer of a political party in the preceding seven years. ${ }^{54}$ This would rule out most significant Fijian leaders over the last decade. Bainimarama wants to depoliticize the GCC, but sees no contradiction in becoming its chair while occupying the highest political office in the land. What he will have at his command is a hand-picked GCC, which will enable him to influence the appointment of President and Vice-President. That, many believe, is his true motive in becoming the chair of the GCC.

\section{Common roll}

As 2007 came to an end, Bainimarama championed with renewed vigour his proposal to create a truly non-racial society. In his 'Road Map' statement, 
Bainimarama had talked of the need to 'rid the Constitution of provisions that facilitate and exacerbate the politics of race', and promised to appoint a Constitution Review Team to address this and other related issues. The team was not appointed; it had been overtaken by the NCBBF and the People's Charter; but Bainimarama continued to speak out in favour of non-racial politics. $\mathrm{He}$ proposed, for example, that all 71 seats in the House of Representatives should be contested from non-racial common roll constituencies. It was a radical proposal, breathtaking in its audacity, and the first of its kind in post-independence Fiji from a Fijian. Bainimarama seemed adamant about it too. The common roll cause, which had once aroused such passionate debate in Fiji, had effectively died in 1969 with the death of its tireless advocate, A.D. Patel. ${ }^{55}$ Since then, every major political leader in Fiji, Fijian and Indo-Fijian alike, had accepted the 'reality' of race as the driver of Fiji politics and worked within its broad parameters.

The proposal drew a cautious response from SDL leader Laisenia Qarase. The 2007 census showed the indigenous Fijians comprising 57 per cent of the total population of 827,900 , while the Indo-Fijian proportion had declined to 37 per cent. The projections are for further decline as Indo-Fijians emigrate and their birthrate remains low. Qarase, like many other Fijian leaders, sensed an advantage in the numbers, which explains his cautious, but encouraging, support. Qarase is mistaken if he thinks that all Fijians will automatically vote for his party, though in the short run many might as the interim administration continues to alienate sizeable sections of the Fijian community. Qarase's willingness to consider a common electoral roll is predicated on his assumption of Fijian solidarity behind his party.

For his part, FLP leader Mahendra Chaudhry has opposed, rhetorically at least, the race-based election system although his stand on complete common roll is not clear. He will be challenged by many in his own community who prefer racially reserved seats because of the illusion of security it gives them, having known no other system. The issue becomes more urgent for them as their numbers dwindle. Thus, it should come as no surprise if the once ardent champions of non-racialism embrace a racially compartmentalized system with guaranteed racial representation.

But, at least on the face of it, all three principal leaders of Fiji-Qarase, Chaudhry and Bainimarama - are agreed on the need to move the country away from race-based politics, providing a basis for further dialogue between them. If there is disquiet about abandoning all the racially reserved seats in one clean sweep, the recommendations of the Reeves Commission for a gradual abandonment of racially reserved seats might be worth considering. The Commission recommended that two thirds (46) of the 71 House of Representative seats should 
be contested from non-racial open seats and one third from racially-reserved ones, with a move to all non-racial open seats over time.

The evolving common ground on this issue notwithstanding, there are several obstacles. The first is Bainimarama's complete unwillingness to engage with Qarase face-to-face on any issue except strictly on his own terms. On 16 November 2007, Qarase wrote to Bainimarama, following earlier correspondence, seeking a meeting and suggesting a pathway out of the current impasse. ${ }^{56}$ Among his suggestions was that the interim administration continue running the affairs of the country until parliament is recalled. The recalled parliament would sit at most for two weeks (for the lower house, and one week for of the Senate) to deal with urgent business. Just before the recall of parliament the interim administration would resign, paving the way for a caretaker cabinet comprising members of the ousted Qarase government to run the country for the duration of the recalled parliament. The prime minister would then resign and advise the president to dissolve the parliament, a caretaker government taking the country to the next general election. The proposal was sensible, if also somewhat convoluted, but worth serious consideration. As Qarase wrote:

Given the will, and allocation of resources, there is no reason why the right of the people to choose their own Government should not be returned to them by the earlier date. We urge Commodore Bainimarama to show good will by aiming for this. Such an action would help to create a more positive and conciliatory national mood. It would find favour with the majority of the populace who back the SDL.

Bainimarama informed the nation that, instead of pondering the matters Qarase had raised, he had thrown the letter straight into the rubbish bin. If Qarase wanted dialogue, he would have to embrace the People's Charter and raise his concerns there. Bainimarama's visceral dislike - hatred might be a more apt word - of the ousted prime minister has shown no sign of diminishing. Bainimarama seems to believe in the old maxim that treating your adversary with respect is giving him an advantage to which he is not entitled. Even entitlements due to a former prime minister have been denied to Qarase in what can only be called petty acts of petulant retribution, especially when Mahendra Chaudhry and Sitiveni Rabuka (and Tevita Momoedonu, who was prime minister for a few hours in 2000, enabling President Ratu Mara to dissolve parliament and call for fresh elections) receive their prime ministerial privileges. Qarase was the country's democratically elected leader for nearly six years.

The second problem flows from the first. Bainimarama insists that the next general election, whenever it is held, will be under a non-racial voting system. But how will the new system be given constitutional legitimacy if it is not authorized by parliament? A decreed electoral system, without the imprimatur of parliament, will find favour with no one. Instead, it will cause further friction 
and division in Fiji. As the saying goes, it is better to debate a question without settling it, than to settle it without debate. But with the military insisting that its way is the only way, prospects of productive dialogue seem bleak.

There was a brief glimmer of hope in March 2008 when Commonwealth envoy and former chairman of the Fiji Constitution Review Commission, Sir Paul Reeves, visited Fiji to mediate between the different political leaders in an effort to break the political deadlock that Fiji found itself in. He had made the trip to Fiji at the invitation of Bainimarama. At first, the interim prime minister was welcoming, as were some of the other leaders, but then Bainimarama, at the behest of the military council, changed his mind and cancelled further meetings with Reeves. Perhaps an important reason for Bainimarama's change of mind might have been the position adopted by the FLP, which refused to participate in the discussions. 'How can it [the FLP] enter into a political dialogue with people whose legitimacy it is challenging?' a party statement asked. ${ }^{57}$ The ousted SDL government had challenged the legality of the interim government in court. In any event, the consultations promised by the NCBBF were much broader and more inclusive and the SDL and other parties could join the dialogue through it. On the face of it, the FLP's position seems disingenuous: After all, it had no difficulty lending support to Sitiveni Rabuka in 1992 while challenging the legitimacy of the constitution that brought him to power. Reeves wanted to explore ways of returning Fiji to early parliamentary democracy, while the FLP wants to postpone the election to beyond 2009, after the People's Charter is in place. An important opportunity was missed.

If a week is a long time in politics, a year is an eternity. Fiji's tale of woes continues. Many issues which precipitated the crisis and held the country to ransom remain unresolved. But if there is one thing certain amidst all the chaos and uncertainty confounding today's Fiji, it is that the military is there to stay for the long haul. It wants for itself an entrenched role in the nation's affairs. The military will no longer simply be an instrument of the state. It will be the ultimate authority overseeing the affairs of the state. A militarized democracy seems in the offing for Fiji.

Despite all the provocation, there was no civil strife in Fiji. Fear of what the military might do, has led to a prudent appreciation of the realities on the ground. After all, the military have all the guns, and their behaviour shows they mean business. More importantly, the prudent reactions of those sections of the Fijian community most aggrieved by the coup have highlighted the serious leadership vacuum in the Fijian community. Laisenia Qarase's enforced exile on his remote island of Mavana in the Lau group deprived his supporters of a leader around whom they could rally. After returning to Suva, Qarase maintained a low profile, quietly consulting party colleagues about the impending court case and other related matters. He was being prudent: He had no choice. Most of his former 
parliamentary colleagues were silent, watching the unfolding events from the sidelines. There was polite protest in the newspapers, although most grumblings remained around the grog bowl.

The GCC reacted similarly to the reforms in its internal structure and composition proposed by the interim administration. The determination to seek resolutions to the country's problems within the legal and constitutional framework augurs well for Fiji, but not too much should be taken for granted. It was refreshing to see those who once decried democracy as a foreign flower unsuited to Fijian soil, publicly embracing democracy as the only way forward. Such are the processes of political transformation in contemporary Fiji. But, as recent history has shown, perceptions and attitudes change fast. Today's self-proclaimed democrats could, without too much contortion, turn into tomorrow's autocrats; the roots of respect for the rule of law and constitutional processes remain very shallow.

The December coup raised a whole host of questions about the kind of society Fiji is and, more importantly, aspires to be. What kind of political culture does it want to bequeath to future generations? Will the military, from now on, be an integral part of the political process, as in Turkey or Thailand or even Pakistan? What role will traditional institutions play in the modern political arena? There were no answers to these questions in 2007. Much was promised, much less accomplished. Robert Rounds of Lautoka spoke for many when he wrote: 'I am tired of the continued promises and fancy choice of words. Fiji needs leaders, we need our leaders to give us reason to believe that we will one day be "the way the world should". Fancy words can only last so long. Leaders do not rule, they lead. Sadly no one is leading our Fiji.' 58

\section{ENDNOTES}

\footnotetext{
1 '365 days later, what's different?' Fiji Sun editorial, 5 December 2007.

2 Fiji Sun, 5 November 2007.

3 Building a Better Fiji for All through a People's Charter for Change and Progress, Draft, Suva, April 2008.

4 See, Fiji Sun, 30 October 2007, Verenaisi Raicola, 'All for the common good', The Fiji Times, 13 October 2007, and Raicola, 'The Way of the Charter', The Fiji Times, 27 September 2007.

5 The Fiji Times Online, 'Church and politics', 25 October 2007.

6 Kevin Barr, 'Law must be balanced by compassion, common sense', The Fiji Times 5 April 2008.

7 'Charter views mixed bag', The Fiji Times Online, 30 October 2007.

8 'Kadavu chief refutes claim', The Fiji Times, 18 January 2008.

9 See Jioji Kotobalavu's thoughts on this, 'Done right, Charter can help', The Fiji Times, 29 October 2007. Also 'Lack of participation hurts Charter, Ratu Joni [Madraiwiwi]', The Fiji Times, 22 March 2008.

10 For details, see my A Time bomb Lies Buried: Fiji's road to Independence, 1960-1970, ANU E Press, Canberra, 2008.

11 'The end is at hand', Fiji Daily Post, 15 March 2008.

12 'Army chief holds key to ending coup culture', The Fiji Times, 18 January 2008.

13 'The danger of one-sided enforced settlements', The Fiji Times editorial, 18 March 2008.

14 'Group to look at military role', The Fiji Times, 22 January 2008.

15 See, Maika Bolatiki, 'Militarisation of civil service', Fiji Sun, 30 June 2007.
} 


\section{The 2006 Military Takeover in Fiji}

16 'Order of battle', The Fiji Times editorial, 20 July 2007.

17 'Perform or move out, says army', The Fiji Times Online, 19 September 2007.

18 'Naipoto backs military postings', The Fiji Times Online, 23 July 2007.

19 See, Maika Bolatiki, '2009 election: Fact or fiction', Fiji Sun 5 January 2008.

20 Forum Communique, Thirty-Eighth Pacific Islands forum, Nuku'alofa, Tonga, 16-17 October 2007.

21 The Fiji Times, 13 September 2007.

22 The Fiji Times, 9 June 2007.

23 'No charter, no election', The Fiji Times, 5 April 2008.

24 'Cabinet Changes Difficult' Fiji Sun editorial, 20 November 2007.

25 See deposed opposition leader Mick Beddoes' comments, 'No evidence on coup claim', in Fiji Sun, 12 November 2007.

26 Verenaisi Raicola, 'All about good governance', The Fiji Times, 17 November 2007. See also, 'FICAC faces uphill battle, Fiji Sun, 27 August 2007 and 'Demarcation of responsibilities', Fiji Sun 19 August 2007. Among other things, the Fiji High Court ruled that FICAC had no constitutional authority to prosecute cases, except through the office of the Director of Public Prosecution.

27 Fatiaki was charged for falsifying his income tax returns for the years 1998-2005, misappropriating an honorarium $(\$ 5,000)$, and, in relation to the 2000 coup, 'actively and voluntarily' taking part 'in the discussion and preparation of advice to the then President to appoint a caretaker Prime Minister, to prorogue Parliament on the advice of the caretaker Prime Minister, thereby breaching his constitutional duty to maintain judicial independence from the executive branch', and in aiding and abetting the abrogation of the constitution'. The Fiji Times, 21 November 2007. On the face of it, the tax charges seem minor. And Fatiaki was not the only judge to be implicated in the constitutional saga following the attempted putsch of 2000.

28 Ceerieann Wilson, 'Is Justice Being Done?' Fiji Sun, 15 September 2007.

29 See, fijilive, 29 June 2007.

30 'Fiji judge urges lawyers to speak out,' fijilive, 25 January 2008.

31 Such as Justice Jocelyn Scutt, who commended a highly controversial report prepared by the director of the Fiji Human Rights Commission, which alleged that the 2006 election was unfair to the Indo-Fijian electorate, when everyone else thought otherwise. See, The Fiji Times editorial 'Protect the judiciary', 19 Febuary 2008.

32 See the article by Nicola Berkovic in The Australian, 11 March 2008.

33 'It's Chaudhry', The Fiji Times, 23 February 2008

34 'Step Aside', The Fiji Times, 6 March 2008.

35 Reported in the Fiji Sun, 17 February 2003.

36 For more details, see Victor Lal, 'Haryana letter tells of \$2m bank deposit', Fiji Sun, 24 February 2008.

37 See, 'Chaudhry is finished: Baba', The Fiji Times, 24 February 2008.

38 Among them was Nadi branch president of the FLP Vijay Prasad, who said that the FLP had made the 'biggest mistake' in joining the interim administration. Fiji Sun, 11 February 2008.

39 'Real story behind the emails', Fiji Sun, 29 February 2008.

40 'Order ignored,' Fiji Sun, 27 February 2008.

41 The interim government subsequently deported Evan Hannah on 1 May 2008.

42 The report was written by Hawaii-based former Fiji trade unionist Dr James Anthony.

43 The statement came from then Labor Foreign Affairs spokesman Robert McClelland, Fiji Sun 28 November 2007.

44 Quoted in Victor Lal, 'Australia shows the coup is not the way', Fiji Sun, 27 November 2007.

45 The report was posted on fijilive website and is also available from the Fiji Human Rights Commission Office, Level 2, Civic Towers, Victoria Parade, Suva.

46 This is from a response prepared for Commissioner Shamima Ali by a group of senior local lawyers rebutting Shameem's paper. Privately circulated.

47 This was also the opinion of three eminent constitutional lawyers: Sir Geoffrey Palmer, QC; Helen Aikman, QC; Alison Quentin-Baxter (New Zealand), and of Professor Cheryl Saunders (Australia). 
48 fijilive, 8 April 2008. Australian Foreign Affairs Minister Stephen Smith: 'This is just another device, another potential distraction to put the interim Fiji Government, the military Government, in the position of sliding out of a faithful undertaking that it gave to the Pacific nation states' to hold elections by March 2009.

49 See my Power and Prejudice: The Making of the Fiji Crisis, New Zealand Institute of International Affairs, Wellington, 1988, pp. 31-38.

50 The quote is from a typescript of the address, available from the Fiji Ministry of Information.

51 On the incidence of poverty, see Wadan Narsey, 'Truth behind our poverty', The Fiji Times, 10 June 2007.

52 For a discussion of the economic impact of the coup, see Chand, this volume.

53 The speech is posted on the Fiji government website.

54 The Fiji Times, 19 February 2008.

55 For a history of the common roll debate, see my A Vision for Change: AD Patel and the politics of Fiji (Canberra, 1997), and the Fiji volume in the British Documents on the End of Empire (London, 2006).

56 This draws on a copy of the letter from Qarase to Bainimarama in my possession. The gist of it was published in the media.

57 'Too late to begin political dialogue', fijilive, 13 March 2008.

58 Robert Rounds, Letters to the Editor, The Fiji Times, 5 January 2008. 